\title{
Affirmative Action as a Majoritarian Device: Or, Do You Really Want to Be a Role Model?
}

Richard Delgado

University of Alabama - School of Law, rdelgado@law.ua.edu

\section{Recommended Citation}

Richard Delgado, Affirmative Action as a Majoritarian Device: Or, Do You Really Want to Be a Role Model?, (2012).

Available at: https://scholarship.law.ua.edu/fac_working_papers/231

This Working Paper is brought to you for free and open access by the Faculty Scholarship at Alabama Law Scholarly Commons. It has been accepted for inclusion in Working Papers by an authorized administrator of Alabama Law Scholarly Commons. 
FOR EDUCATIONAL USE ONLY

89 Mich. L. Rev. 1222

Michigan Law Review

March, 1991

Essay

*1222 AFFIRMATIVE ACTION AS A MAJORITARIAN DEVICE: OR, DO YOU REALLY WANT TO BE A ROLE MODEL?

\author{
Richard Delgado [FNa]
}

Copyright 1991 by the Michigan Law Review Association; Richard Delgado

Have you ever noticed how affirmative action occupies a place in our system of law and politics far out of proportion to its effects in the real world? Liberals love talking about and sitting on committees that define, oversee, defend, and give shape to it. [FN1] Conservatives are attached to the concept for different reasons: they can rail against it, declare it lacking in virtue and principle, and use it to rally the troops. [FN2] Affirmative action is something they love to hate. The program also generates a great deal of paper, conversation, and jobs probably more of the latter for persons of the majority persuasion than it has for its intended beneficiaries. Yet, despite its rather meager accomplishments and dubious lineage, a number of us have jumped on the bandwagon, [FN3] maybe because it seemed one of the few that would let us on.

But should we? Lately, I have been having doubts, as have other writers of color. [FN4] In this essay I examine several of the reasons why. First, I address some doubts about affirmative action generally. Then I focus on the role model argument, a component of affirmative action *1223 that until recently has received less scrutiny than it deserves. [FN5] I explain the majority group's attraction to the role model argument, but urge professionals of color to reject that approach in favor of other, more liberating relations between themselves and their communities.

\title{
I. THE AFFIRMATIVE ACTION MYSTIQUE: LET THE BANDWAGON ROLL RIGHT ON
}

Scholars of color have grown increasingly skeptical about both the way in which affirmative action frames the issue of minority representation and the effects that it produces in the world. Affirmative action, I have noticed, generally frames the question of minority representation in an interesting way: Should we as a society admit, hire, appoint, or promote some designated number of people of color in order to promote certain policy goals, such as social stability, an expanded labor force, and an integrated society? [FN6] These goals are always forward-looking; affirmative action is viewed as an instrumental device for moving society from state $A$ to state B. [FN7] The concept is neither backward-looking nor rooted in history; it is teleological rather than deontological. [FN8] Minorities are hired or promoted not because we have been unfairly treated, denied jobs, deprived of our lands, or beaten and $* \mathbf{1 2 2 4}$ brought here in chains. [FN9] Affirmative action neatly diverts our attention from all those disagreeable details and calls for a fresh start. [FN10] Well, where are we now? So many Chicano bankers and chief executive officers, so many black lawyers, so many Native American engineers, and so many women physicians. What can we do to increase these numbers over the next ten or twenty years? The system thus bases inclusion of people of color on principles of social utility, not reparations or rights. When those in power decide the goal has been accomplished, or is incapable of being reached, what logically happens? Naturally, the program stops. [FN11] At best, then, affirmative action serves as a homeostatic device, assuring that only a small number of women and people of color are hired or promoted. [FN12] Not too many, for that would be terrifying, nor too few, 
for that would be destabilizing. Just the right small number, generally those of us who need it least, are moved ahead. [FN13]

Affirmative action also neatly frames the issue so that even these small accomplishments seem troublesome, requiring great agonizing and gnashing of teeth. Liberals and moderates lie awake at night, asking how far they can take this affirmative action thing without sacrificing innocent white males. [FN14] Have you ever wondered what that makes us - if not innocent, then . . . ? Affirmative action enables members of the dominant group to ask, "Is it fair to hire a less-qualified Chicano or black over a more-qualified white?" [FN15] This is a curious way of framing the question, as I will argue in a moment, in part because those who ask it are themselves the beneficiaries of history's largest affirmative action program. This fact is rarely noticed, however, while $* \mathbf{1 2 2 5}$ the question goes on causing the few of us who are magically raised by affirmative action's unseen hand to feel guilty, undeserving, and stigmatized. [FN16]

Affirmative action, as currently understood and promoted, is also ahistorical. For more than 200 years, white males benefited from their own program of affirmative action, through unjustified preferences in jobs and education resulting from old-boy networks and official laws that lessened the competition. [FN17] Today's affirmative action critics never characterize that scheme as affirmative action, which of course it was. By labeling problematic, troublesome, and ethically agonizing a paltry system that helps a few of us get ahead, critics neatly take our eyes off the system of arrangements that brought and maintained them in power, and enabled them to develop the rules and standards of quality and merit that now exclude us, make us appear unworthy, dependent (naturally) on affirmative action.

Well, if you were a member of the majority group and invented something that cut down the competition, made you feel good and virtuous, made minorities grateful and humble, and framed the "minority problem" in this wondrous way, I think you would be pretty pleased with yourself. Moreover, if you placed the operation of this program in the hands of the very people who brought about the situation that made it necessary in the first place, society would probably reward you with prizes and honors.

Please do not mistake what I am saying. As marginalized people we should strive to increase our power, cohesiveness, and representation in all significant areas of society. [FN18] We should do this, though, because we are entitled to these things and because fundamental fairness requires this reallocation of power. We should reformulate the issue. Our acquiescence in treating it as "a question of standards" is absurd and self-defeating when you consider that we took no part in creating those standards and their fairness is one of the very things we want to call into question. [FN19]

Affirmative action, then, is something no self-respecting attorney $* 1226$ of color ought to support. We could, of course, take our own program, with our own goals, our own theoretical grounding, and our own managers and call it "Affirmative Action." But we would, of course, be talking about something quite different. My first point, then, is that we should demystify, interrogate, and destabilize affirmative action. The program was designed by others to promote their purposes, not ours. [FN20]

\section{THE ROLE MODEL ARGUMENT}

In this Part, I address an aspect of affirmative action mythology, the role model argument, that in my opinion has received less criticism than it deserves. [FN21] This argument is a special favorite of moderate liberals, who regard it as virtually unassailable. [FN22] Although the argument's inventor is unknown, its creator must have been a member of the majority group and must have received a prize almost as large as the one awarded the person who created affirmative action itself. Like the larger program of which it is a part, the role model argument is instrumental and forward-looking. It makes us a means to another's end. [FN23] A whitedominated institution hires you not because you are entitled to or deserve the job. Nor is the institution seeking to set things straight because your ancestors and others of your heritage were systematically excluded from such jobs. Not at all. You're hired (if you speak politely, have a neat haircut, and, above all, can be trusted) not because of your accomplishments, but because of what others think you will do for them. If they hire you now and you are a good role model, things will be better in the next generation. [FN24] 
Suppose you saw a large sign saying, "ROLE MODEL WANTED. GOOD PAY. INQUIRE WITHIN." Would you apply? Let me give you five reasons you should not.

Reason Number One. Being a role model is a tough job, with long hours and much heavy lifting. [FN25] You are expected to uplift your entire $* 1227$ people. Talk about hard, sweaty work! [FN26]

Reason Number Two. The job treats you as a means to an end. Even your own constituency may begin to see you this way. "Of course Tanya will agree to serve as our faculty advisor, give this speech, serve on that panel, or agree to do us $X, Y$, or $Z$ favor, probably unpaid and on short notice. What is her purpose if not to serve us?" [FN27]

Reason Number Three. The role model's job description is monumentally unclear. If highway workers or tax assessors had such unclear job descriptions, they would strike. If you are a role model, are you expected to do the same things your white counterpart does, in addition to counseling and helping out the community of color whenever something comes up? [FN28] Just the latter? Half and half? Both? On your own time, or on company time? [FN29] No supporter of the role model argument has ever offered satisfactory answers to these questions.

Reason Number Four. To be a good role model, you must be an assimilationist, [FN30] never a cultural or economic nationalist, separatist, radical reformer, or anything remotely resembling any of these. As with actual models (who walk down runways wearing the latest fashions), you are expected to conform to prevailing ideas of beauty, politeness, grooming, and above all responsibility. If you develop a quirk, wrinkle, aberration, or, heaven forbid, a vice, look out! [FN31] I have heard more than once that a law school would not hire $X$ for a teaching position because, although $\mathrm{X}$ might be a decent scholar and good classroom teacher, he was a little exuberant or rough around the edges and thus not good role model material. Not long ago, Margaret $* 1228$ Court, the ex-tennis star and grand dame of English tennis officialdom, criticized Martina Navratilova as a poor role model for young tennis players. [FN32] Martina failed Court's assessment not because she served poorly, wore a wrinkled tennis uniform, displayed bad sportsmanship, or argued with the referees. Rather, in Court's opinion, Martina was not "straight," not "feminine" enough, and so could not serve as a proper role model. [FN33] Our white friends always want us to model behavior that will encourage our students and protégés to adopt majoritarian social mores; you never hear of them hiring one of their number because he or she is bilingual, wears dashikis, or is in other ways like us.

Reason Number Five (the most important one). The job of role model requires that you lie that you tell not little, but big, whopping lies, and that is bad for your soul. Suppose I am sent to an inner city school to talk to the kids and serve as role model of the month. I am expected to tell the kids that if they study hard and stay out of trouble, they can become a law professor like me. [FN34] That, however, is a very big lie: a whopper. When I started teaching law sixteen years ago, there were about thirty-five Hispanic law professors, approximately twenty-five of which were Chicano. Today, the numbers are only slightly improved. [FN35] In the interim, however, a nearly complete turnover has occurred. The faces are new, but the numbers have remained the same from year to year. [FN36] Gonzalez leaves teaching; Velasquez is hired somewhere else. Despite this, I am expected to tell forty kids in a crowded, inner city classroom that if they work hard, they can each be among the chosen twenty-five. [FN37] Fortunately, most kids are smart enough to figure out that the system does not work this $* 1229$ way. If I were honest, I would advise them to become major league baseball players, or to practice their hook shots. As Michael Olivas points out, the odds, pay, and working conditions are much better in these other lines of work. [FN38]

Recently, the California Postsecondary Commission, concerned about the fate of minorities in the state's colleges and universities, [FN39] had its statisticians compile a projection for all young blacks starting public school in California that year. That number was about 35,000 . Of these, the statisticians estimated that about one half would graduate from high school, the rest having dropped out. Of those completing high school, approximately one out of nine would attend a four-year college. Of that number, about 300 would earn a bachelor's degree. You can form your own estimate of how many of this group, which began as 35,000, will continue on to earn a law degree. Thirty? Fifty? And of these, how many will become law professors? My guess is one, at most. But I may be an optimist. [FN40] 
Suppose I told the ghetto kids these things, that is, the truth. And, while I am at it, told them about diminishing federal and state scholarship funds that formerly enabled poor kids to go to college, [FN41] about the special threat to assistance for minority college students, [FN42] and about a climate of increasing hostility, slurs, and harassment on the nation's campuses. [FN43] Suppose I told them, in short, what the system is really like, how the deck is stacked against them. What would happen? I would quickly be labeled a poor role model and someone else sent to give the inspiring speech next month.

\section{*1230 III. WHY THINGS ARE THE WAY THEY ARE AND WHAT CAN BE DONE}

The role model theory is a remarkable invention. It requires that some of us lie and that others of us be exploited and overworked. The theory is, however, highly functional for its inventors. It encourages us to cultivate nonthreatening behavior in our own people. In addition, it provides a handy justification for affirmative action, which, as I have pointed out, is at best a mixed blessing for communities of color.

As with any successful and popular program, I think we need only examine the functions served by the role model argument to see why our white friends so readily embrace it. Demographers tell us that in about ten years, Caucasians will cease to be the largest segment of California's population. [FN44] In approximately sixty years, around the year 2050, the same will happen nationally. [FN45] While this radical demographic shift is occurring, the population also will be aging. [FN46] The baby boomers, mostly white, will be retired and dependent on social security for support. [FN47] These retirees will rely on the continuing labor of a progressively smaller pyramid of active workers, an increasing proportion of them of color. You see, then, why it is essential that we imbue our next generation of children with the requisite respect for hard work. They must be taught to ask few questions, pay their taxes, and accept social obligations, even if imposed by persons who look different from them and who committed documented injustices on their ancestors. [FN48]

If you want the job of passing on that set of attitudes to young people of color, go ahead. You will be warmly received and amply rewarded. But you do not have to be a role model. You can do other more honorable, authentic things. You can be a mentor. [FN49] You can be an "organic intellectual," [FN50] offering analysis and action programs for *1231 our people. You can be a matriarch, a patriarch, a legend, or a provocateur. [FN51] You can be a socially committed professional who marches to your own drummer. You can even be yourself. But to the ad, ROLE MODEL WANTED, the correct answer, in my view, is: NOT ME! FNa Charles Inglis Thomson Professor of Law, University of Colorado. J.D. 1974, University of California, Berkeley. - Ed.

FN1. Almost every major law review has devoted space to the treatment, usually sympathetic and from a liberal standpoint, of affirmative action. See e.g., sources noted in Delgado, The Imperial Scholar: Reflections on a Review of Civil Rights Literature, 132 U. PA. L. REV. 561, 562 n.3 (1984); see also L. TRIBE, AMERICAN CONSTITUTIONAL LAW 1521-44, 1565-71 (2d ed. 1988) (discussion of affirmative action, or "benign" classification, in areas of race and sex).

FN2. See e.g., Abram, Affirmative Action: Fair Shakers and Social Engineers, 99 HARV. L. REV. 1312 (1986); Graglia, Special Admission of the "Culturally Deprived" to Law School, 119 U. PA. L. REV. 351 (1970); see also Carter, The Best Black and Other Tales, RECONSTRUCTION, Winter 1990 , at 6 (middle-of-the-road criticism of affirmative action as psychologically deleterious to its purported beneficiaries).

FN3. Some writers of color who have supported affirmative action are cited in Delgado, supra note 1, at 576 n.76; see also Leonard, A Step Toward Equality: Affirmative Action and Equal Employment Opportunity, 4 BLACK L.J. 214 (1974).

FN4. E.g., D. BELL, AND WE ARE NOT SAVED: THE ELUSIVE QUEST FOR RACIAL JUSTICE 14061 (1987); Carter, supra note 2; Delgado, Book Review, Derrick Bell and the Ideology of Racial Reform: Will We Ever Be Saved?, 97 YALE L.J. 923, 923-24, 933 (1988). 
FN5. The role model argument, in simplest form, holds that affirmative action is justified in order to provide communities of color with exemplars of success, without which they might conclude that certain social roles and professional opportunities are closed to them. Role models are expected to communicate to their communities that opportunities are indeed available and that hard work and perseverance will be rewarded. See Kennedy, Persuasion and Distrust: A Comment on the Affirmative Action Debate, 99 HARV. L. REV. 1327, 1329 (citing as benefits of affirmative action "the expansion of a professional class able to pass . . . elevated aspirations to subsequent generations" and "teaching whites that blacks, too, are capable of handling responsibility."). But see Wygant v. Jackson Bd. of Educ., 416 U.S. 267, 274-76 (1986) (plurality opinion) (rejecting role modeling as justification for racial classifications protecting minority teachers against disproportionate layoffs).

Recently, the issue of role modeling was brought to the fore when Derrick Bell, a prominent African-American law professor, took unpaid leave from his position at Harvard because of the school's refusal to hire a black woman professor. See Markoff, Action of Harvard's Prof. Bell Focuses Attention on Diversity, Natl. L.J., May 7, 1990, at 4. Bell, the country's most noted black law professor, left his position in part because of his growing realization that he could not serve as an adequate role model for black women law students.

FN6. I discuss this cheerful, forward-looking perspective in Delgado, supra note 1, at 569-71. Lyndon Johnson created affirmative action when he issued Executive Order 11,246 on September 24, 1965, during a period of intense racial turmoil. Exec. Order No. 11,246, 30 Fed. Reg. 12,319 (1965). For cases and materials relating to its early implementation, see J. JONES, W. MURPHY \& R. BELTON, DISCRIMINATION IN EMPLOYMENT 587-683, 989-1012 (5th ed. 1987). For interpretive discussion of affirmative action's role in maintaining white ascendancy, see infra text accompanying notes 10-17 and sources cited therein.

FN7. Delgado, supra note 1, at 570 ("The past becomes irrelevant; one just asks where things are now and where we ought to go from here, a straightforward social-engineering inquiry of the sort that law professors are familiar with and good at.").

FN8. Id. (forward-looking perspective avoids need to dwell on "unpleasant matters like lynch mobs, segregated bathrooms, Bracero programs, or professional schools that, until recently, were lily white").

FN9. See Delgado, supra note 4, at 934-41 for a brief description. For a longer treatment, see L. HIGGINBOTHAM, IN THE MATTER OF COLOR (1978).

FN10. Delgado, supra note 1 , at 569-70. For the view that this future-oriented approach is, in fact, desirable, see Sullivan, The Supreme Court, 1985 Term - Comment: Sins of Discrimination: Last Term's Affirmative Action Cases, 100 HARV. L. REV. 78 (1986). For the contrary view that affirmative action is based on making amends for past injustices or providing a "level playing field," see Sher, Justifying Reverse Discrimination, in EQUALITY AND PREFERENTIAL TREATMENT 49 (1977).

FN11. Delgado, supra note 1, at 570 ("Moreover, what if the utility calculus changes in the future, so that the programs no longer appear 'useful' to the majority? Can society then ignore those who still suffer the effects of past discrimination?").

FN12. Delgado, supra note 4, at 923-24 (attributing this general view to Derrick Bell, whose "interest-convergence" approach to racial jurisprudence has revolutionized critical thought on matters of race). For discussion of "interest convergence" see Bell, Brown v. Board of Education and the Interest-Convergence Dilemma, 93 HARV. L. REV. 518 (1980).

FN13. See D. BELL, supra note 4, at 140-61. 
FN14. See Sullivan, supra note 10, at 91-96 (arguing that sin-based approach to affirmative action causes this problem).

FN15. For a poignant recounting of a talented black's encounter with this attitude, see Carter, supra note 2.

FN16. See id.; Kennedy, Racial Critiques of Legal Academia, 102 HARV. L. REV. 1745, 1795-96, 1801-07, 1817-18 (1989).

FN17. Delgado, Approach-Avoidance in Law School Hiring: Is the Law a WASP?, 34 ST. LOUIS U. L.J. 631,639 (1990).

FN18. For a discussion of whether the dominant group will ever peaceably allow this to happen to any significant extent, see Delgado, supra note 4, at 942-45.

FN19. On the absurdity of using current standards to judge challenges to those very standards, see Delgado, When A Story Is Just a Story: Does Voice Really Matter?, 76 VA. L. REV. 95, 10002 (1990); Delgado, Brewer's Plea: Critical Thoughts On Common Cause, 44 VAND. L. REV. 1 , 8-10 (1991) [hereinafter Brewer's Plea].

FN20. See supra text accompanying notes 6-18 (Affirmative action is soothing, limiting, and therapeutic for whites but psychologically and materially injurious to populations of color.).

FN21. The term is defined supra note 5.

FN22. The argument is unanswerable only in a factual sense: common-sense understandings of human nature hold that persons tend to emulate successful individuals who are like themselves.

FN23. See infra notes 44-48 and accompanying text (speculating that role modeling, as currently understood, is aimed at perpetuating current social relations in the years ahead, when the demography of the United States will have radically changed).

FN24. In other words, the next generation of people of color will be like the industrious, wellmannered role model. See infra notes $44-48$ and accompanying text.

FN25. For a dreary picture of such a life, see Delgado, Minority Law Professors' Lives: The BellDelgado Survey, 24 HARV. C.R.-C.L. L. REV. 349, 369 (1989) (reporting survey results and concluding: "It is impossible to read the ... returns without being acutely conscious of the pain and stress they reflect. Large numbers of minority law professors are overworked, excluded from informal information networks and describe their work environment as hostile, unsupportive, or openly or subtly racist."); Pierce, Unity in Diversity: Thirty-Three Years of Stress, Solomon Carter Fuller Lecture, Am. Psychiatric Assn. Meeting, Wash., D.C. (May 12, 1986) (on file with author) (same).

FN26. Pierce, supra note 25; see also Brooks, Life After Tenure: Can Minority Law Professors Avoid the Clyde Ferguson Syndrome?, 20 U.S.F. L. REV. 419 (1986) (overwork and overcommitment produce serious risk of early death for professionals of color in high-visibility positions).

FN27. See Delgado, supra note 25 , at $360,367-68$.

FN28. Id. Most professors of color of my acquaintance do an inordinate amount of counseling, recruiting, and speaking on behalf of minority causes. See also Brooks, supra note 26.

FN29. On the time pressures minority professors of color labor under, see generally Delgado, supra note 25 , at $355-56$. 
FN30. On assimilationism, see Brewer's Plea, supra note 19. On black nationalism and separatism, see D. BELL, supra note 4 , at 215-35 and D. BELL, RACE, RACISM AND AMERICAN LAW 47-51 (2d ed. 1980).

FN31. On the intense scrutiny that role models encounter, see Brooks, supra note 26 and Delgado, supra note 25.

FN32. Downey, She Succeeds As A Person, As An Athlete, L.A. Times, July 16, 1990, at C1, col. 2.

FN33. Id. (hinting that Navratilova's alleged bisexuality disabled her from serving as a role model for aspiring female tennis players).

FN34. Most minority law professors of color (if we are honest) know we got our positions either by luck - by being in the right place at the right time - or as a result of student pressure and activism. This, of course, is not what our majority-race friends and supervisors want us to say to our protégés and communities.

FN35. Telephone interview with Michael Olivas, Professor of Law, University of Houston, Director, Institute of Higher Education Law and Governance (Sept. 1990). Professor Olivas is a member of various Association of American Law Schools and other professional committees that track the numbers of professors of color in law teaching. For current figures, see Lempinen, A Student Challenge to the Old Guard, STUDENT LAW., Sept. 1990, at 12, 15 (citing 1990 figure from Olivas of 51 Latino faculty members).

FN36. See Delgado, supra note 25, at 350-51 n.7 (noting the high attrition and turnover rates of law professors of color).

FN37. This is, of course, mathematically impossible. Perhaps we are only expected to announce that any given one of the students could aspire to be in the circle of 25, or more modestly, could become any type of professor, or lawyer, or professional, or white-collar worker, or clerk, or paralegal, or legal secretary, or ..... But this would rob the role-model argument of any significance. It would also leave unexplained why sending a Chicano legal assistant (not a law professor) would not do.

FN38. Interview with Michael Olivas, supra note 35. Olivas has recounted this story to several professional groups and committees, where it has always been greeted with dismay. The message is clear. Even if true, one should not say such things!

FN39. Address by Manning Marable, University of Colorado (Sept. 1990), reporting apparently unpublished results of the Commission's survey. See Why All the Dropouts? (editorial), L.A. Times, Dec. 27, 1985, Part II, at 4, col. 1.

FN40. The future looks grim especially given that these dismal statistics came from California, our most populous, most ethnically diverse, and possibly most progressive state.

FN41. See Making College More Costly: Tighter Loan Rules Will Squeeze Schools, Parents and Students, TIME, Mar. 23, 1981, at 89 (working-and middle-class families hard hit by decreases in federal scholarship and loan aid).

FN42. On the cutback of tutoring and other support services for disadvantaged students that is occurring nationwide see Marriott, Scholarships Aimed at Minorities Banned, Denver Post, Dec. 12,1990 , at 1 , col. 4.

FN43. For a survey of some of the more notorious incidents, see Delgado, Campus Antiracism 
Rules: Constitutional Narratives in Collision, 85 NW. U. L. REV. 343 (1991).

FN44. Several national magazines have covered the increasing influence of nonwhite cultures on American society, e.g., A Surging New Spirit, TIME, July 11, 1988, at 46 (growing Hispanic population and changes it is producing in national culture).

FN45. Marable, supra note 39; cf. Barringer, census shows Profound Changes in Racial Makeup of the Nation, N.Y. Times, Mar. 11, 1991, at A1, col. 1 (regional and ethnic group analysis of changes in U.S. population based on latest census).

FN46. See DeMott, New Look at the Elderly, TIME, Feb. 18, 1985, at 81; Hornblower, Gray Power!, TIME, Jan. 4, 1988, at 36.

FN47. See sources cited supra note 46.

FN48. See Delgado, supra note 4, at 935-41. For an arresting account of Native Americans' fate at the hands of the early U.S. political-legal system, see R. WILLIAMS, THE AMERICAN INDIAN IN WESTERN LEGAL THOUGHT: THE DISCOURSES OF CONQUEST 227-323 (1990).

FN49. I.e., one who tells aspiring young persons of color truthfully what it is like to practice your profession in a society dominated by race.

FN50. Attributed to Italian Criticalist Antonio Gramsci, the term refers to a people's intellectual who operates in a nonhierarchical fashion and places his or her talents at the service of social reform.

FN51. In recent times, the most inspired (and maligned) example of most of these things is Derrick Bell, whose imaginative chronicles and acts of nonviolent resistance at Harvard (including a sit-in in his own office and, later, teaching his own classes while on unpaid leave) have galvanized us all.

89 MILR 1222

END OF DOCUMENT 